\title{
Effect of biodegradable coatings on the shelf life of Hancornia speciosa $a^{1}$
}

\author{
Naiara Tays Francisco Felicio², Suzane Martins Ferreira², \\ Taysa Martins de Oliveira ${ }^{2}$, Emmerson Rodrigues de Moraes $^{2}$, Dayana Silva Batista Soares ${ }^{2}$
}

\section{ABSTRACT}

The production of Hancornia speciosa Gomes, in Brazil, has increased significantly in recent years, with a concomitant increase in post-harvest losses, making it important to find out new techniques that contribute to extend the shelf life of this fruit without altering its physical, sensory and nutritional characteristics. The present study aimed to apply biodegradable coatings made from chitosan, whey protein, lactic acid and cassava starch to $H$. speciosa, as well as to assess their efficiency on the shelf life of the fruits. For that, physico-chemical analyses were performed to determine the $\mathrm{pH}$, acidity, ${ }^{\circ} \mathrm{Brix}$, phenolic compounds, vitamin $\mathrm{C}$ and moisture content. The coatings with $1 \%$ of chitosan, $4 \%$ of whey protein, $3 \%$ of cassava starch and $1.5 \%$ of lactic acid presented satisfactory results at ambient temperature $\left(25^{\circ} \mathrm{C}\right)$, delaying the ripening process, when compared to the controls.

KEYWORDS: Brazilian Savanna, tropical fruit, post-harvest losses.

\section{INTRODUCTION}

The Brazilian Savanna is Brazil's second largest biome and covers approximately 2 million $\mathrm{km}^{2}$, representing $25 \%$ of the country's surface (Menezes Filho \& Castro 2019). Among the native fruits of this biome, Hancornia speciosa Gomes stands out for its high nutritional value, containing $1.20 \%$ of protein, $2.37 \%$ of lipids, $10.0 \%$ of carbohydrates, $3.40 \%$ of fiber, vitamins A, B1, B2 and C, as well as minerals such as phosphorus, calcium and iron (Soares et al. 2006). H. speciosa offers a variety of health benefits due to its high concentrations of natural antioxidants, including ascorbic acid, carotenoids and phenolic compounds (Almeida et al. 2011).

\section{RESUMO}

Efeito de coberturas biodegradáveis no tempo de vida útil de Hancornia speciosa

A produção de mangaba (Hancornia speciosa Gomes), no Brasil, tem aumentado consideravelmente nos últimos anos e, paralelamente a esse grande volume produzido, há elevado percentual de perdas, o que torna necessário o conhecimento de novas técnicas que contribuam para estender o tempo de vida útil dos frutos sem alterar suas características físicas, sensoriais e nutricionais. Objetivou-se aplicar coberturas biodegradáveis de quitosana, proteína do soro de leite, ácido lático e fécula de mandioca em mangaba, bem como avaliar a sua eficiência na preservação do tempo de vida útil dos frutos. Para isso, foram realizadas análises físico-químicas de $\mathrm{pH}$, acidez, ${ }^{\circ} \mathrm{Brix}$, compostos fenólicos, vitamina $\mathrm{C}$ e umidade. As coberturas com $1 \%$ de quitosana, $4 \%$ de proteína do soro de leite, $3 \%$ de fécula de mandioca e 1,5\% de ácido lático apresentaram resultados satisfatórios em temperatura ambiente $\left(25^{\circ} \mathrm{C}\right)$, retardando o amadurecimento, em relação aos controles.

PALAVRAS-CHAVE: Cerrado, frutos tropicais, perdas póscolheita.

Post-harvest losses are associated with factors such as storage, handling and inadequate transport, affecting intermediate and final consumers. These factors are responsible for high losses during the commercialization process and, consequently, for a significant portion of the considerable difference between wholesale and retail prices (Chitarra \& Chitarra 2005). H. speciosa fruits have an average shelf life of 3 days when harvested ripen, whereas green fruits take around 9 days to ripen and lose their sensory qualities at an average temperature of $20^{\circ} \mathrm{C}$ (Siqueira et al. 2018).

According to Fellows (2019), edible films and coatings are used to preserve fruits after harvesting. Produced from different natural materials, they act

\footnotetext{
${ }^{1}$ Received: Aug. 04, 2020. Accepted: Sep. 15, 2020. Published: Feb. 05, 2021. DOI: 10.1590/1983-40632021v5164825.

${ }^{2}$ Instituto Federal Goiano, Campus Morrinhos, Morrinhos, GO, Brasil.Email/ORCID: naiara.tays@gmail.com/0000-0003-0376-1094, suzane.ferreira@ifgoiano.edu.br/0000-0001-6516-7205, taysaamartins@gmail.com/0000-0001-8332-1181, emmerson.moraes@ifgoiano.edu.br/0000-0002-9616-4688,dayana.soares@ifgoiano.edu.br/0000-0002-6148-3726.
} 
as a natural barrier to protect food from deterioration or contamination, and retain vitamins and minerals in order to preserve the nutritional value of the product. A coating is a fine layer of material formed and applied directly onto the surface of the product, while a film is preformed separately and subsequently applied (Fakhouri et al. 2007). Research on biopolymer-based coatings such as polysaccharides, proteins and lipids has increased due to their ability to extend the shelf life of food (Rodrigues et al. 2019). In addition, coatings can act as agents in the transportation of active substances such as antimicrobials to the food surface (Ribeiro et al. 2007, Soares et al. 2011).

The present study aimed to assess the effect of different types of edible coatings made from cassava starch, chitosan, whey protein and lactic acid on extending the shelf life of $H$. speciosa stored at ambient temperature.

\section{MATERIAL AND METHODS}

The experiment was conducted at the Instituto Federal Goiano, in Morrinhos, Goiás state, Brazil $\left(17^{\circ} 48^{\prime} 45.2^{\prime \prime} \mathrm{S}\right.$ and $\left.49^{\circ} 12^{\prime} 14.5^{\prime \prime} \mathrm{W}\right)$, from October to November 2019. The H. speciosa fruits were selected and harvested in the morning in the halfripen stage, subjectively classified according to skin color (greenish yellow) and firmness (slightly hard), as described by Nasser et al. (2016). Next, they were transported to the laboratory, sanitized with sodium hypochlorite (100 ppm) for $10 \mathrm{~min}$ and rinsed under running water, followed by analyses and coating application. The formulations used to coat the fruits are described in Table 1.

For the $4 \%$ whey protein coating, an aqueous solution was prepared with glycerol $(2 \%)$ and unflavored gelatin $(2 \%)$ in distilled water $(92 \%)$, manually homogenized and heated at $90{ }^{\circ} \mathrm{C}$ for $30 \mathrm{~min}$. The chitosan (1\%) coating contained lactic acid $(1 \%)$ and unflavored gelatin (2\%) solubilized in distilled water (96\%) and was manually homogenized before application. The formulation of the lactic acid $(1.5 \%)$ coating consisted of unflavored gelatin (2\%) solubilized in distilled water $(96.5 \%)$, which was manually shaken prior to application. The cassava starch (3\%) coating contained unflavored gelatin ( $2 \%)$ solubilized in distilled water $(95 \%)$, was shaken slowly and gradually heated to $70{ }^{\circ} \mathrm{C}$, maintaining this temperature for $10 \mathrm{~min}$ to enable gelation, then cooled at ambient temperature before application.

Except for the control samples, the fruits were immersed in the corresponding coatings for approximately $5 \mathrm{~min}$ and allowed to dry naturally on polystyrene trays. They were then stored at ambient temperature $\left(25^{\circ} \mathrm{C}\right)$ and assessed in triplicate every two days. The methodologies used here were in accordance with the Instituto Adolfo Lutz (2008) and the Association of Official Analytical Chemists (2007). The fruits were assessed to determine the soluble solids content ( ${ }^{\circ}$ Brix) by refractometry (IAL2008); the vitamin $\mathrm{C}$ content (ascorbic acid) expressed in mg $100 \mathrm{~g}^{-1}$ (IAL2008); the phenolic compounds determined by spectrophotometry $(720 \mathrm{~nm}$ ) (Swain \& Hills 1959); the gallic acid solution used as standard in concentrations ranging from 0 to $100 \mathrm{mg} \mathrm{mL}^{-1}$ and the result expressed in $\mathrm{mg}$ of gallic acid/g of sample; the titratable acidity expressed in $\%$ of citric acid (IAL 2008); the $\mathrm{pH}$ determined with a digital potentiometer; and the moisture content expressed in $\%$ per $\mathrm{m} / \mathrm{m}$ (AOAC 2007).

A completely randomized two-factor (coating $x$ storage time) design was used, with three replications. The data were submitted to analysis of variance using the F-test, at $5 \%$ of significance. Polynomial regression was performed when the interaction was significant and the test of means when non-significant, using the MiniTab software, version 9 beta.

\section{RESULTS AND DISCUSSION}

The titratable acidity of the $H$. speciosa fruits during storage varied from 0.27 to $0.98 \%$ of citric acid per sample (Figure 1).

Table 1. Formulations of the whey protein, chitosan, lactic acid and cassava starch coatings.

\begin{tabular}{lllc}
\hline \multicolumn{1}{c}{ Whey protein } & \multicolumn{1}{c}{ Chitosan } & \multicolumn{1}{c}{ Lactic acid } & Cassava starch \\
\hline Glycerol $(2 \%)$ & Chitosan $(1 \%)$ & Lactic acid $(1.5 \%)$ & Unflavored gelatin $(2 \%)$ \\
Unflavored gelatin $(2 \%)$ & Lactic acid $(1 \%)$ & Unflavored gelatin $(2 \%)$ & Cassava starch $(3 \%)$ \\
Whey protein $(4 \%)$ & Unflavored gelatin $(2 \%)$ & Distilled water $(96.5 \%)$ & Distilled water $(95 \%)$ \\
Distilled water $(92 \%)$ & Distilled water $(96 \%)$ & - & - \\
\hline
\end{tabular}




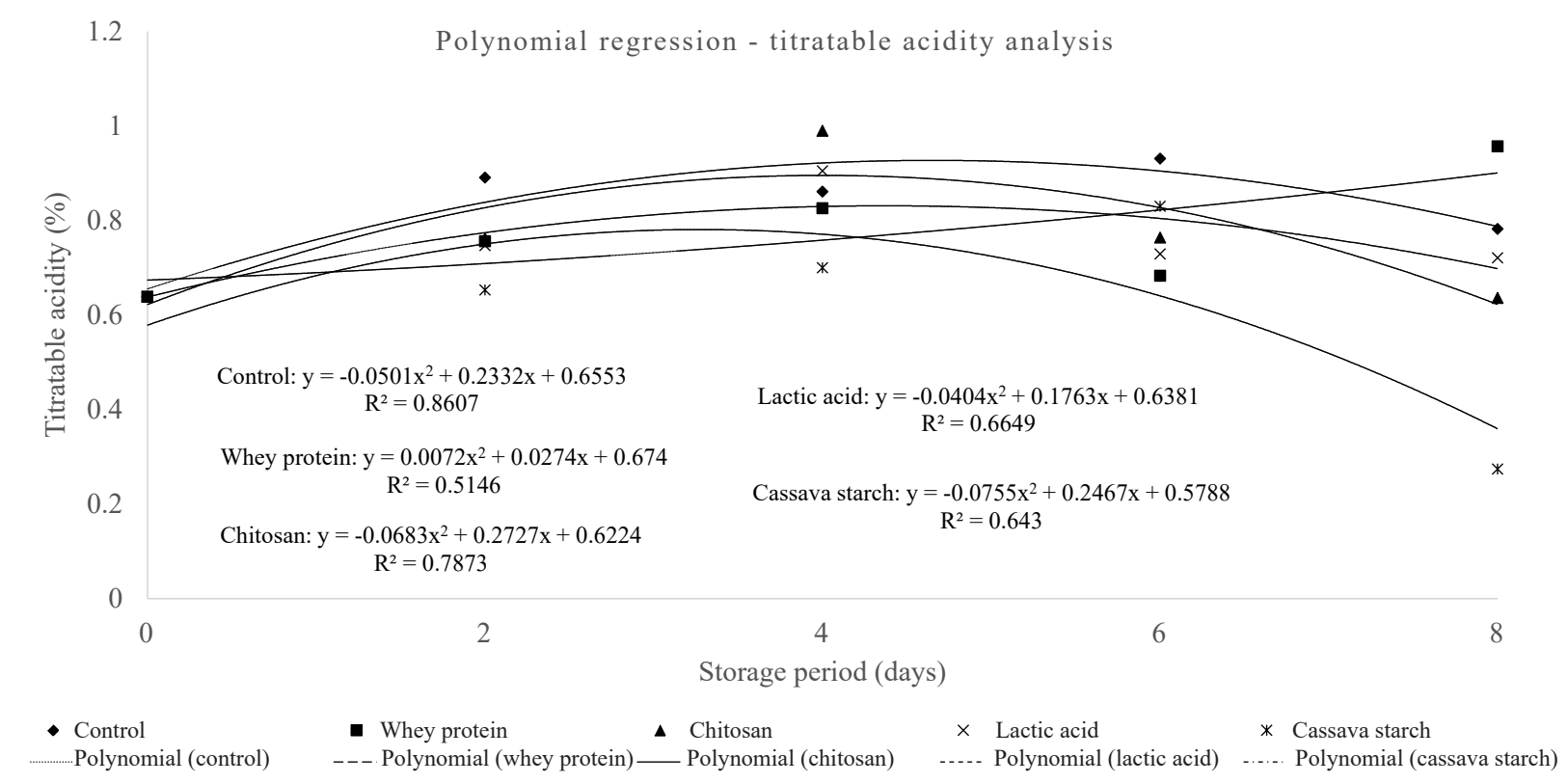

Figure 1. Titratable acidity ( $\%$ of citric acid) for each treatment applied to Hancornia speciosa fruits stored at ambient temperature $\left(25^{\circ} \mathrm{C}\right)$ for eight days.

Except for the whey protein coating, all the treatments showed a gradual increase in acidity during storage followed by a decrease, with a larger decrease observed in the cassava starch-coated samples on the eighth day of storage. According to Chitarra \& Chitarra (2005), the acid content of plants decreases as fruits ripen, because acids are used as substrate in respiration or converted into sugars and are important in the fruit flavor and aroma.

A different behavior was observed for the whey protein-coated samples (Figure 1), with an increase in acidity at the end of storage. Several authors have reported that the $H$. speciosa acidity tends to increase during storage, and that may be an inherent characteristic of the fruit during ripening (Carnelossi 2004, Narain 2005, Carnelossi 2009). Another hypothesis for this increase is cell wall degradation due to metabolism, with an increase in the number of organic acids in the fruit (Siqueira et al. 2013).

The $\mathrm{pH}$ of the H. speciosa fruits during storage varied from 4.12 to 4.84 (Figure 2).

Silva et al. (2009) found that the $\mathrm{pH}$ of Brazilian Savanna fruits ranges from 3.10 at the onset of ripening to 3.40 at the end, being lower than the values obtained here, likely because the authors stored the $H$. speciosa fruits at $-18^{\circ} \mathrm{C}$ for thirty days.

The chitosan-coated samples exhibited the largest increase in $\mathrm{pH}$ during storage. According to
Rocha et al. (2001), the increase in $\mathrm{pH}$ is directly related to the decrease in acidity, attributed to the consumption of organic acids during respiration. The $\mathrm{pH}$ of the whey protein-coated fruits fluctuated, with the lowest variation observed on the fourth day of storage, when compared to the other coatings.

The results of the soluble solids content analysis are expressed in Figure 3.

The ${ }^{\circ}$ Brix values of the samples coated with chitosan, lactic acid and cassava starch showed a similar behavior during storage, with an increase in soluble solids on the second and sixth days and a decrease on the fourth and last days of storage. This fluctuation may be due to the difference in physiological maturity of the fruits at harvest, since the controls and wheyprotein-coated $H$. speciosa fruits exhibited an increase in the soluble solids content values on day six and a decrease on the last day. The increase in the soluble solids content during ripening may be attributed to the conversion of solids, such as carbohydrate reserves, into simple sugars, such as glucose, fructose and sucrose, resulting in a higher concentration of soluble solids content (Chitarra \& Chitarra 2005).

Additionally, a number of chemical and biochemical reactions occur as fruits ripen, such as decreased acidity and increase in the soluble solids content. The soluble solids content decrease at the end of ripening, indicating that sugars from starch 


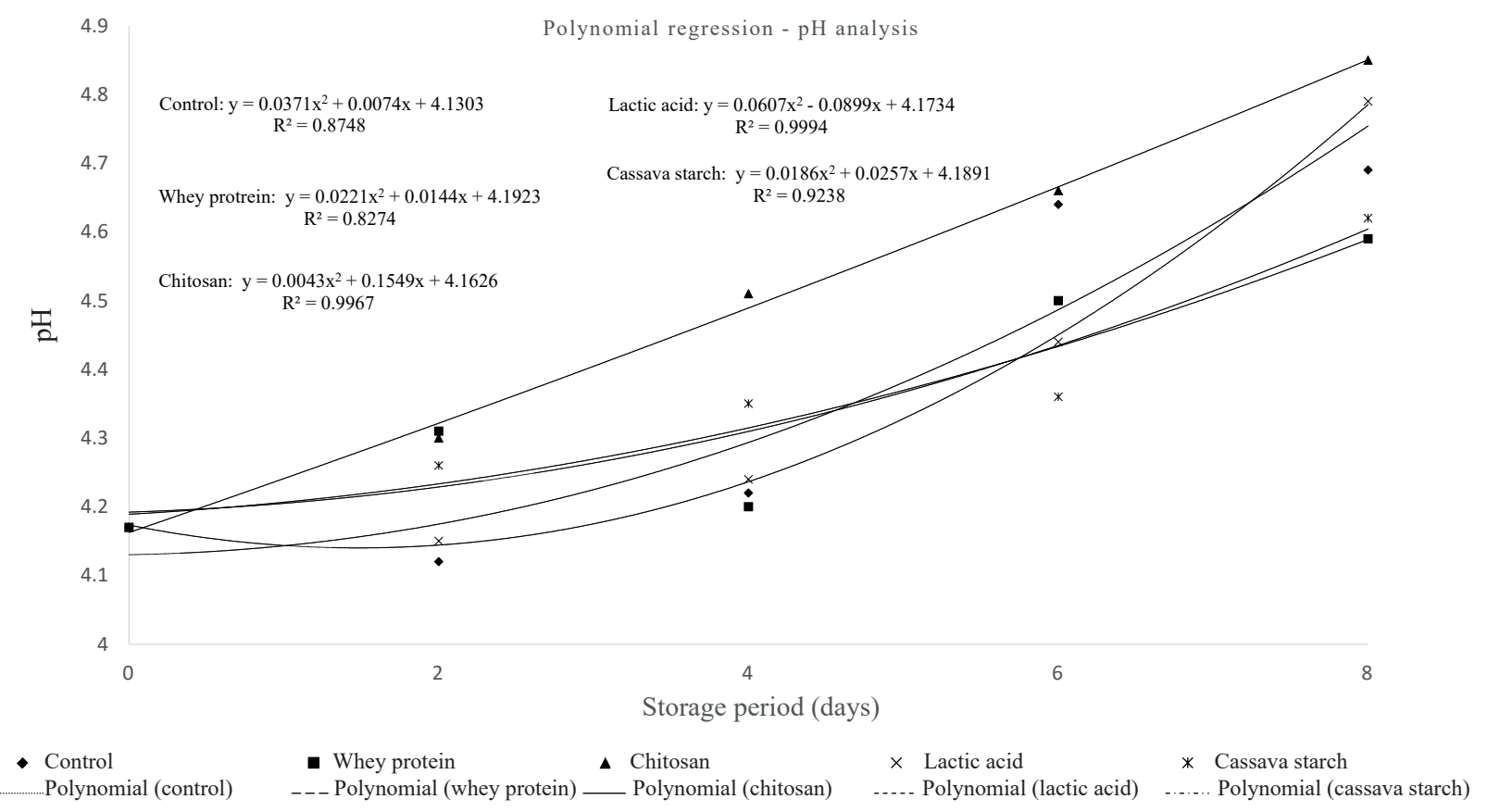

Figure 2. Results of the $\mathrm{pH}$ analysis for each treatment applied to Hancornia speciosa fruits stored at ambient temperature $\left(25^{\circ} \mathrm{C}\right)$ for eight days.

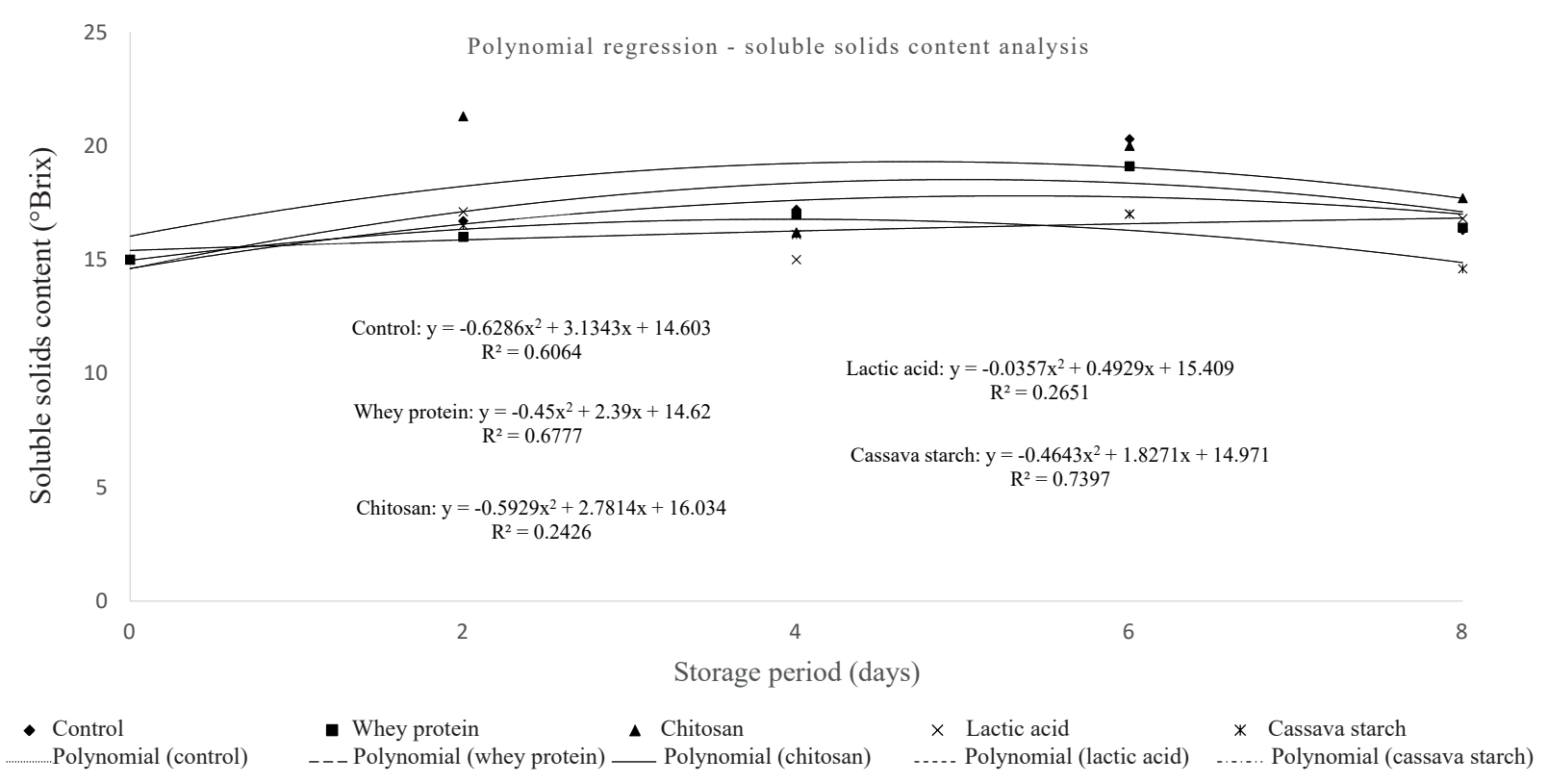

Figure 3. Soluble solids content for each treatment applied to Hancornia speciosa fruits stored at ambient temperature $\left(25^{\circ} \mathrm{C}\right)$ for eight days.

hydrolysis are being used as an energy source for fruit respiration; in other words, it is the onset of senescence (Morais et al. 2006). This suggests that the fruits studied here were likely entering senescence at the end of the storage period.
The ascorbic acid (vitamin C) content of the samples is described in Figure 4.

The vitamin $\mathrm{C}$ analysis showed a considerable decrease at the end of storage, with a value of






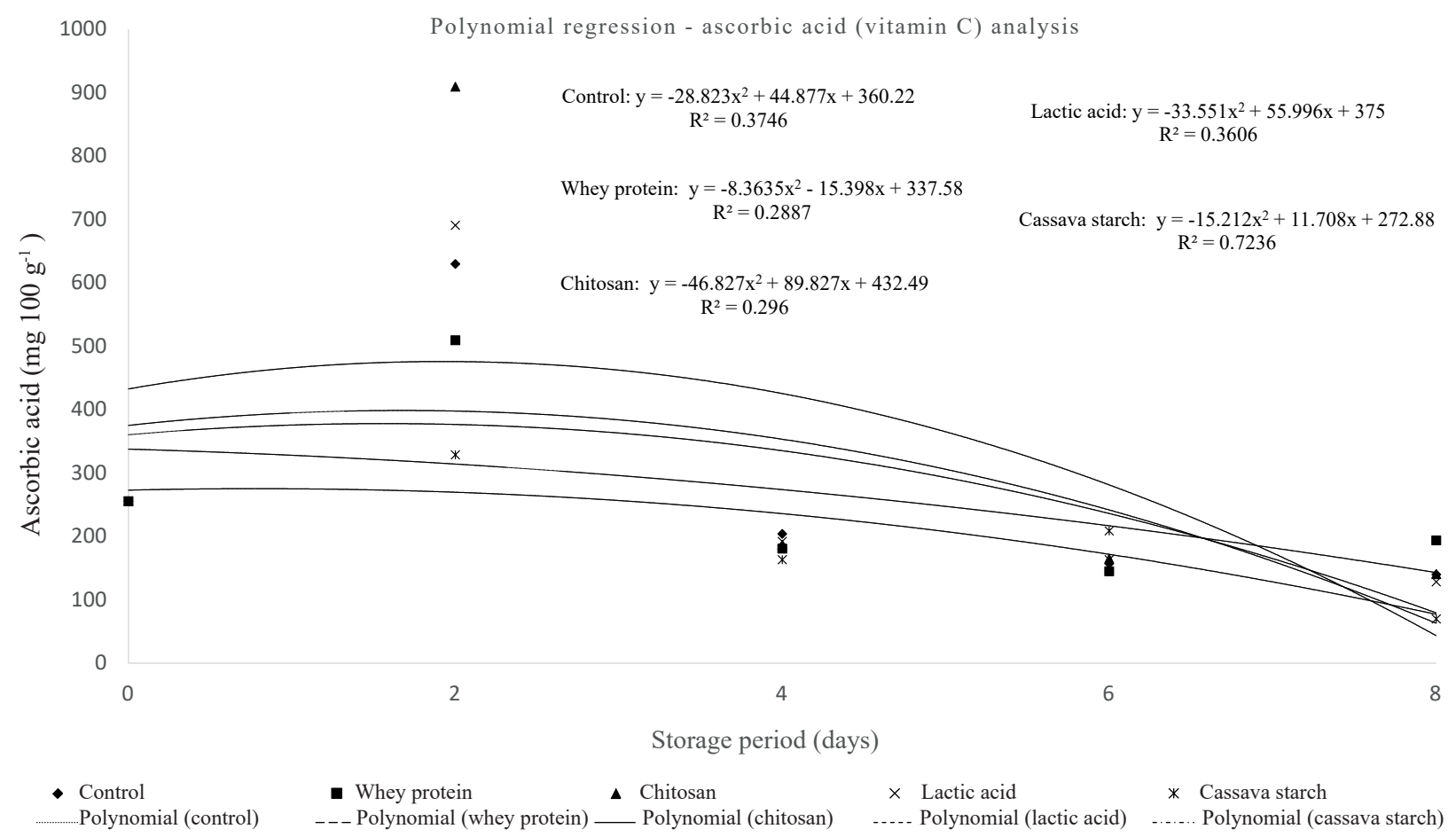

Figure 4. Ascorbic acid content for each treatment applied to Hancornia speciosa fruits stored at ambient temperature $\left(25^{\circ} \mathrm{C}\right)$ for eight days.

ascorbic acid found in $H$. speciosa fruits treated with a $2 \%$ chitosan coating at a controlled temperature of $1-3{ }^{\circ} \mathrm{C}$ (Nasser et al. 2016). A high value of $909.10 \mathrm{mg} 100 \mathrm{~g}^{-1}$ was recorded for the chitosan treatment. All the tested samples showed an increase in the vitamin $\mathrm{C}$ content on the second day, attributed to the action of ascorbic acid as an antioxidant, in response to the accelerated oxidative reactions that occur during ripening, since the $H$. speciosa fruits analyzed here were harvested close to physiological maturity, when the synthesis of intermediate metabolites increases, promoting glucose 6-phosphate synthesis, an immediate precursor of ascorbic acid (Perfeito et al. 2015). There was a significant decrease in the ascorbic acid content in all the treatments on the fourth assessment day. $H$. speciosa is a fast-ripening fruit and, in general, the vitamin $\mathrm{C}$ content, expressed as ascorbic acid, decreases as ripening progresses, due to the action of ascorbic acid oxidase (Nogueira 2011).

The analysis of variance (Anova) showed no significant interaction $(p<0.05)$ between the coatings and moisture content, with interaction only observed for storage time. The moisture content of the tested samples is presented in Figure 5.
With respect to the moisture content, values were higher on the final day of storage for the protein coating, when compared to the other treatments, despite the decrease from day four to six. The controls displayed less moisture loss on day four of storage, when compared to the coated samples.

The second highest moisture content $(84.77 \%$ ) was recorded for the cassava starch coating on the final day of storage, albeit not statistically different from the remaining samples (Table 2). Coatings can act as a modified atmosphere, changing the composition of gases available to the fruits, and the $\mathrm{O}_{2}$ availability generally decreases and the $\mathrm{CO}_{2}$ concentration increases, interfering in climacteric respiration (Praseptiangga et al. 2017). It should also be noted that the cassava starch coating can act as a barrier to water loss due to transpiration. Transpiration, characterized by water loss, leads to wilting and tissue softening, making the fruit more susceptible to deterioration, as well as changes in flavor and appearance (Hojo et al. 2007).

The analysis of variance (Anova) showed no significant interaction $(p<0.05)$ between the coatings and phenolic compound content, with interaction only observed for storage time. The phenolic compound content of coated $H$. speciosa fruits 


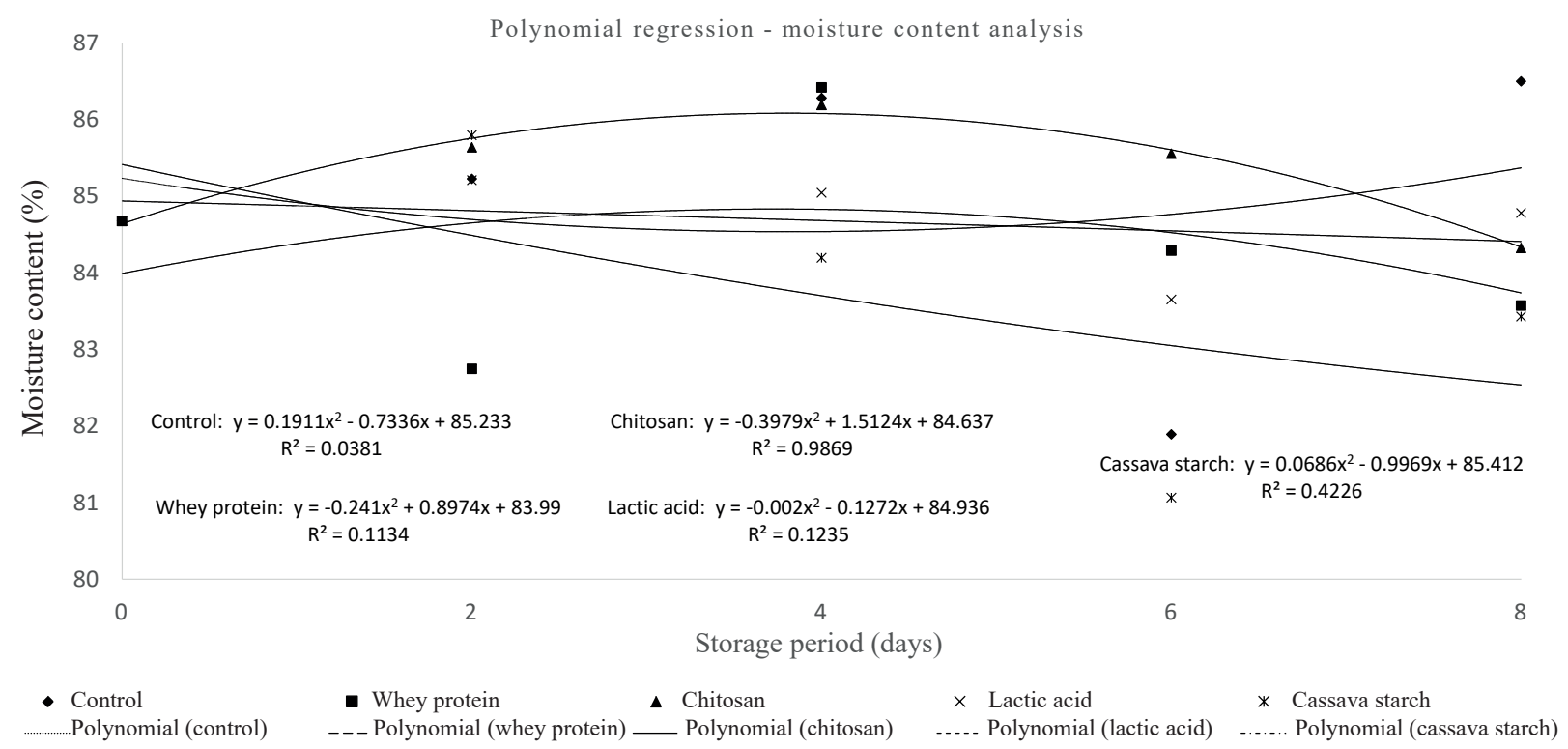

Figure 5. Moisture content for each treatment applied to Hancornia speciosa fruits stored at ambient temperature $\left(25^{\circ} \mathrm{C}\right)$ for eight days.

Table 2. Moisture content (\%) for each treatment applied to Hancornia speciosa fruits stored at ambient temperature $\left(25^{\circ} \mathrm{C}\right)$ for eight days.

\begin{tabular}{|c|c|c|c|c|c|}
\hline \multirow{2}{*}{ Day } & \multicolumn{5}{|c|}{ Treatments } \\
\hline & Control & Whey protein & Chitosan & Lactic acid & Cassava starch \\
\hline 0 & $84.67 \mathrm{~A}^{*} \pm 0.74$ & $84.67 \mathrm{~A} \pm 0.74$ & $84.67 \mathrm{~A} \pm 0.74$ & $84.67 \mathrm{~A} \pm 0.74$ & $84.67 \mathrm{~A} \pm 0.74$ \\
\hline 2 & $85.79 \mathrm{~A} \pm 0.15$ & $85.22 \mathrm{~B} \pm 0.39$ & $82.74 \mathrm{~B} \pm 0.81$ & $85.63 \mathrm{~A} \pm 0.30$ & $85.20 \mathrm{~A} \pm 0.20$ \\
\hline 4 & $84.19 \mathrm{BC} \pm 0.14$ & $86.27 \mathrm{~A} \pm 0.39$ & $86.41 \mathrm{~A} \pm 0.23$ & $86.18 \mathrm{~A} \pm 0.09$ & $85.04 \mathrm{~B} \pm 0.36$ \\
\hline 6 & $81.07 \mathrm{~A} \pm 2.22$ & $81.89 \mathrm{~A} \pm 2.21$ & $84.29 \mathrm{~B} \pm 2.17$ & $85.55 \mathrm{~A} \pm 0.67$ & $83.64 \mathrm{~A} \pm 0.61$ \\
\hline 8 & $83.43 \mathrm{~A} \pm 1.96$ & $86.49 \mathrm{~A} \pm 0.34$ & $83.57 \mathrm{~A} \pm 1.29$ & $84.32 \mathrm{~A} \pm 0.55$ & $84.77 \mathrm{~A} \pm 1.67$ \\
\hline
\end{tabular}

* Different letters in the same row indicate a significant difference among treatments $(\mathrm{p}=0.05)$, according to the Tukey test.

increased during ripening and decreased at the end of storage (Figure 6). These compounds contribute to flavor and coloring.

Phenolic compound concentration is related to antioxidant capacity and may be used to monitor post-harvest quality loss (Chitarra \& Chitarra 2005).
The whey protein coating exhibited the highest


final day of storage, but did not differ statistically from the remaining treatments on the same day (Table 3 ). On day six, values for all the treatments increased considerably, in relation to the other assessment days,

Table 3. Results of the phenolic compound analysis ( $\mathrm{mg} 100 \mathrm{~g}^{-1}$ of sample) for each treatment applied to Hancornia speciosa fruits stored at ambient temperature $\left(25^{\circ} \mathrm{C}\right)$ for eight days.

\begin{tabular}{|c|c|c|c|c|c|}
\hline \multirow{2}{*}{ Day } & \multicolumn{5}{|c|}{ Treatments } \\
\hline & Control & Whey protein & Chitosan & Lactic acid & Cassava starch \\
\hline 0 & $2.22 \mathrm{~A}^{*} \pm 0.53$ & $2.22 \mathrm{~A} \pm 0.53$ & $2.22 \mathrm{~A} \pm 0.53$ & $2.22 \mathrm{~A} \pm 0.53$ & $2.22 \mathrm{~A} \pm 0.53$ \\
\hline 2 & $27.24 \mathrm{~A} \pm 0.46$ & $20.01 \mathrm{BC} \pm 0.70$ & $16.17 \mathrm{C} \pm 3.74$ & $21.66 \mathrm{~B} \pm 0.35$ & $24.50 \mathrm{AB} \pm 0.66$ \\
\hline 4 & $33.58 \mathrm{CD} \pm 0.88$ & $51.48 \mathrm{AB} \pm 0.91$ & $42.22 \mathrm{BC} \pm 10.43$ & $23.92 \mathrm{D} \pm 11$ & $58.97 \mathrm{~A} \pm 0.64$ \\
\hline 6 & $82.60 \mathrm{~A} \pm 2.96$ & $85.61 \mathrm{~B} \pm 13.13$ & $72.39 \mathrm{~A} \pm 32$ & $77.62 \mathrm{~A} \pm 3.50$ & $65.25 \mathrm{~A} \pm 6.37$ \\
\hline 8 & $10.28 \mathrm{~A} \pm 2.19$ & $12.06 \mathrm{~A} \pm 1.84$ & $7.59 \mathrm{~A} \pm 3.02$ & $9.88 \mathrm{~A} \pm 1.00$ & $7.57 \mathrm{~A} \pm 0.67$ \\
\hline
\end{tabular}

* Different letters in the same row indicate a significant difference among treatments $(\mathrm{p}=0.05)$, according to the Tukey test. 


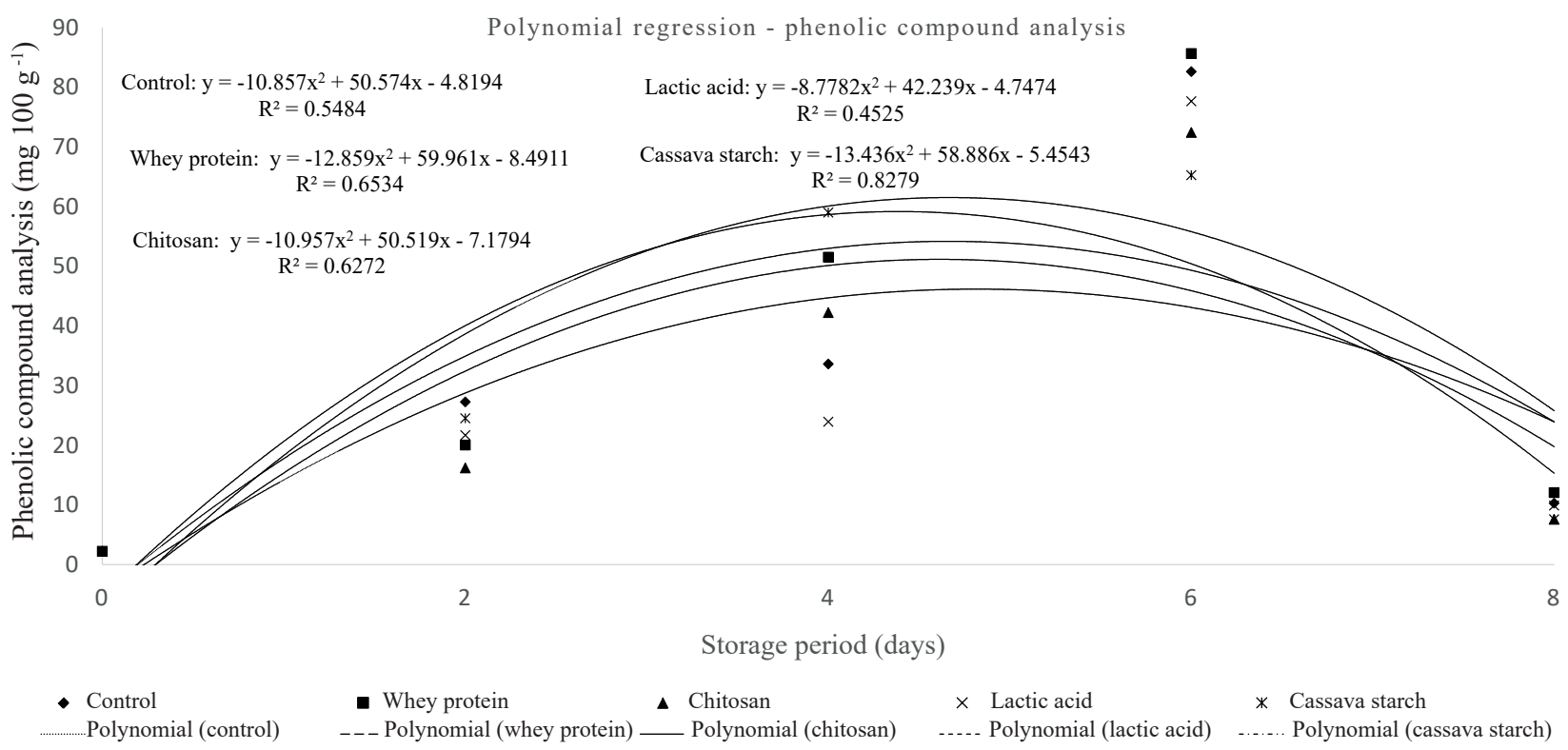

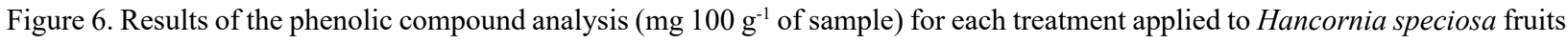
stored at ambient temperature $\left(25^{\circ} \mathrm{C}\right)$ for eight days.

with a maximum of $85.61 \mathrm{mg} 100 \mathrm{~g}^{-1}$, which is lower

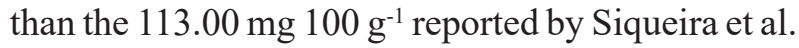
(2013) for total phenolic compounds.

\section{CONCLUSION}

Under the applied concentrations and conditions, the assessment of the effect of biodegradable coatings on the post-harvest shelf life of Hancornia speciosa fruits stored at ambient temperature $\left(25^{\circ} \mathrm{C}\right)$ indicated that the best acidity, $\mathrm{pH}$ and soluble solids content results are obtained for coatings with $1 \%$ of chitosan, $4 \%$ of whey protein, $3 \%$ of cassava starch and $1.5 \%$ of lactic acid, delaying ripening, when compared to the controls.

\section{ACKNOWLEDGMENTS}

The authors are grateful to the Instituto Federal Goiano, for the funding, additional support and facilities provided to conduct the study.

\section{REFERENCES}

ALMEIDA, M. M. B.; SOUSA, P. H. M.; ARRIAGA, A. M. C.; PRADO, G. M.; MAGALHÃES, C. E. C.; MAIA, G. A.; LEMOS, T. L. G. Bioactive compounds and antioxidant activity of fresh exotic fruits from northeastern Brazil. Food Research International, v. 44, n. 7, p. $2155-$ 2149, 2011.

CARNELOSSI, M. A. G. Conservação pós-colheita de mangaba (Hancornia speciosa Gomes). Ciência e Agrotecnologia, v. 28, n. 5, p. 1119-1125, 2004.

CARNELOSSI, M. A. G. Physico-chemical quality changes in mangaba (Hancornia speciosa Gomes) fruit stored at different temperatures. Brazilian Archives of Biology and Technology, v. 52, n. 4, p. 985-990, 2009.

CHITARRA, M. I. F.; CHITARRA, A. B. Pós-colheita de frutas e hortaliças: fisiologia e manuseio. Lavras: Ed. UFLa, 2005.

FAKHOURI, F. M.; FONTES, L. C. B.; GONÇALVES, P. V. M.; MILANEZ, C. R.; STEEL, C. J.; QUEIROZ, F. P. C. Filmes e coberturas comestíveis compostas à base de amidos nativos e gelatina na conservação e aceitação sensorial de uvas Crimson. Ciência e Tecnologia de Alimentos, v. 27, n. 2, p. 369-375, 2007.

FELLOWS, P. J. Tecnologia do processamento de alimentos: princípios e prática. 4. ed. Porto Alegre: Artmed, 2019.

HOJO, E. T. D.; CARDOSO, A. D.; HOJO, R. H.; VILAS BOAS, E.; ALVARENGA, M. A. R. Uso de películas de fécula de mandioca e PVC na conservação pós-colheita de pimentão. Ciência e Agrotecnologia, v. 31, n. 1, p. 184190, 2007. 
INSTITUTO ADOLFO LUTZ (IAL). Métodos físicoquímicos para análise de alimentos. 3. ed. São Paulo: Instituto Adolfo Lutz, 2008.

MENEZES FILHO, A. C. P.; CASTRO, C. F. S. Identificação das classes de metabólitos secundários em extratos etanólicos foliares de Campomanesia adamantium, Dimorphandra mollis, Hymenaea stigonocarpa, Kielmeyera lathrophytum e Solanum lycocarpum. Estação Científica, v. 9, n. 1, p. 89-101, 2019.

MORAIS, P. L. D.; LIMA, L. C. O.; ALVES, R. E.; FILGUEIRAS, H. A. C.; ALMEIDA, A. S. Alterações físicas, fisiológicas e químicas durante o armazenamento de duas cultivares de sapoti. Pesquisa Agropecuária Brasileira, v. 41, n. 4, p. 1-3, 2006.

NARAIN, N. A cultura da mangaba. Aracaju: Embrapa Tabuleiros Costeiros, 2005.

NASSER, F. A. C. M.; BOLIANI, A. C.; NASSER, M. D.; PAGLIARINI, M. K.; MENDONÇA, V. Z. Conservação de mangabas submetidas à aplicação de quitosana. Revista de Ciências Agrárias, v. 44, n. 3, p. 279-285, 2016.

NOGUEIRA, F. S. Teores de ácido l-ascórbico em frutas e sua estabilidade em sucos. Tese (Mestrado em Produção Vegetal) - Universidade Estadual do Norte Fluminense Darcy Ribeiro, Campos dos Goytacazes, 2011.

PERFEITO, D. G. A.; CARVALHO, N.; LOPES, M. C. M.; SCHIMIDT, F. L. Caracterização de frutos de mangabas (Hancornia speciosa Gomes) e estudo de processos de extração da polpa. Revista de Agricultura Neotropical, v. 2, n. 3, p. 1-7, 2015.

PRASEPTIANGGA, D.; UTAMI, R.; KHASANAH, L. U.; EVIRANANDA, I. P.; KAWIJI. Effect of cassava starch-based edible coating incorporated with lemongrass essential oil on the quality of papaya MJ9. IOP Conference Series: Materials Science and Engineering, v. 176, n. 1, p. 1-5, 2017.
RIBEIRO, C.; VICENTE, A. A.; TEIXEIRA, J. A.; MIRANDA, C. Optimization of edible coating composition to retard strawberry fruit senescence. Postharvest Biology and Technology, v. 44, n. 1, p. 63-70, 2007.

ROCHA, R. H. C.; MENEZES, J. B.; MORAIS, E. A.; AMBRÓSIO, M. M.; ALVEZ, M. Z. Uso do índice de degradação de amido na determinação da maturidade da manga 'Tommy Atkins'. Revista Brasileira de Fruticultura, v. 23, n. 2, p. 302-305, 2001.

RODRIGUES, A. O.; LUCIO, E. C. B.; MELO, L. C.; SILVA, M. C. F. C. Biopolímero desenvolvido a partir da farinha de arroz e sua aplicação como revestimento em frutos. Revista Brasileira de Aplicações de Vácuo, v. 38, n. 2, p. 103-107, 2019.

SILVA, A. M. L.; MARTINS, B. A.; DEUS, T. N. Avaliação do teor de ácido ascórbico em frutos do Cerrado durante o amadurecimento e congelamento. Estudos, v. 36, n. 6, p. 1159-1169, 2009.

SIQUEIRA, A. P. S.; MORGADO, C. M. A.; CAVALCANTE, K. A.; CUNHA JUNIOR, C.; SOUZA, E. R. B. Vida útil de mangaba do Cerrado em diferentes estádios de maturação. Revista de Agricultura Neotropical, v. 5, n. 3, p. 91-96, 2018.

SIQUEIRA, E. M. A; ROSA, F. R.; FUSTINONI, A. M.; SANT'ANA, L. P. de; ARRUDA, S. F. Brazilian Savanna fruits contain higher bioactive compounds content and higher antioxidant activity relative to the conventional red delicious apple. Plos One, v. 8, n. 1, p. 72-82, 2013.

SOARES, F. P.; PAIVA, R.; NOGUEIRA, R. C.; OLIVEIRA, L. M.; SILVA, D. R. G. e; PAIVA, P. D. O. Cultura da mangabeira (Hancornia speciosa Gomes). Lavras: Ed. UFLa, 2006. (Boletim agropecuário, 67).

SOARES, N. F. F.; SILVA, D. F. P.; CAMILLOTO, G. P.; OLIVEIRA, C. P.; PINHEIRO, N. M.; MEDEIROS, E. A. A. Antimicrobial edible coating in post-harvest conservation of guava. Revista Brasileira de Fruticultura, v. esp., p. 281-289, 2011. 